\title{
Optimization of Land Use Collaborative Management Model Perum Perhutani: Study Case KPH Pekalongan Barat
}

\author{
Anugrahandini Nasir ${ }^{1 *}$, Muhamad Buce Saleh², Bahruni \\ ${ }^{1}$ Graduate School of Bogor Agricultural University, Dramaga main Road, Campus IPB Dramaga, Bogor, Indonesia 16680 \\ ${ }^{2}$ Department of Forest Management, Faculty of Forestry, Bogor Agricultural University, Academic Ring Road, Campus IPB \\ Dramaga, Po Box 168, Bogor, Indonesia 16680
}

Received February 11, 2017/Accepted April 17, 2017

\begin{abstract}
Perhutani is mandated to manage approximately 2,445,006 ha forest in Java consisting of a production forest area of 1,806,449 ha and protected forest area of 638,558 ha (Perhutani 2014). Perhutani working area consists of several units of governance in the form of Forest Management Units (KPH). Currently, 57 KPH Perhutani are experiencing various problems that the function of conservation isnot going well. KPH Pekalongan Barat is one of the KPH which is considered quite good. It can be seen from the compliance percentage each year that reaches about 90\%. The approach used in this research is 1) financial feasibility analysis, 2) land use optimization analysis, 3) multi-criteria analysis. The first analysis is financial feasibility analysis. The research's output based on the financial aspect performs that the feasibility criteria of investment of the three land use options are feasible to execute. The broad composition for optimal land use is an area covering 11047 ha of pine, a coffee area of 2126 ha and vegetable area 668 ha with an income of IDR872,581,112,943. According to multi-criteria analysis, the existing vegetable area is in an unfeasible area, so it can be durable.
\end{abstract}

Keywords: income, KPH Pekalongan Barat, land optimization, multi-criteria, Perhutani

*Correspondence author, email: anugrahandininasirr@gmail.com,ph.: +62-85299481547

\section{Introduction}

Some activities based on land become the factors which make the forest ecosystem functions are going down (Dewi et al. 2014). The pressure impacts to the change of forest cover that brings the unstable life of flora, fauna, water's quality, and land. Conserving the natural resources has been being the main topic for some researchers especially those who expert in land use (Xiao et al. 2006). The majority activities of land use work on land water run-off areas and land's quality (Bradshaw et al. 2007; Lin et al. 2007; Hurkmans et al. 2009). Concerning with those activities, the first step is finding the actuality of land use which is being an urgency to understand the change of land use from forest to non-forest (Turner et al. 2007). According to that issue, it is needed a good plan and management of forest management system. The concept of Lestari forest management has been being the ideal forest management for years. FAO (1994) defines Lestari forest management as a management and preserving of natural resources which concerns with technology and institution change to fulfill human's needs continuously. Perhutani is responsible for superintending around $2,445,006$ ha forest region in Java island which consists of production forest region around 1,806,449 ha and preserved forest region 638,558 ha (Perhutani 2014). The Perhutani region consists of some units which are well-known as KPH. Currently, 57 of KPHs are having a problem called the unfunctional conservation.

KPH Pekalongan Barat becomes the better ones that can be seen from the percentage of latex fulfilling in every year that is able to reach around $90 \%$. KPH Pekalongan Barat efforts a pine company class in order to maximize the income of the forest management unit. Instead of producing pine latex as an income, the forest management unit of West Pekalongan manages the water source of wana as a natural tourism. Then the quality of forest natural resources and forest degradation are existed because of social pressure such as vegetable land cultivation in the forest region. It indicates that the main structure is going down such as the abnormal of age class, the decrease of $n$ per ha (numbers of trees) and the accessibility caused by decreasing of latex productivity. In the social management, the deal faced is the land cultivation by the people. It implicates to the business management system of Perum Perhutani particularly the forest management unit of Pekalongan Barat. The existing of business management system will be decreased if the natural resources in the forest destroyed or managed unwell. The effort for the forest by Lestari has been done by the forest management unit of Pekalongan Barat since several years 
ago. The exchange dynamic of social and economic implicates to the ecology of natural sources by giving a challenge of managing the forest management unit in Pekalongan Barat.

The optimal and intensive of land use is needed to do in $\mathrm{KPH}$ Pekalongan Barat throughout the management preparation. The preparation effort is needed in order to determine the land's characteristics and qualities. This process has been done before the recovering process of the forest management unit. It needs to be done first because it can be thought as a strategic step in fixing up the forest management of Perum Perhutani. The recovering process of the forest management unit is started by management plan which is based on management unit types. The management plan provides some management options for all stakeholders. A management option is a commodity option which is developed through collaborative management scheme. Nevertheless, the management option produced by the KPH Pekalongan Barat is a pine option (Perhutani), coffee (local government), vegetables (citizens). The forest management is expected to be multi-function. Thus, it needs an optimum approach for an economic, ecological, and social aspect of the forest ecosystem (Suhendang 2005). This is important because these characteristics are quite substantial to achieve by Lestari forest management (Davis et al. 2001).

The analyses used in this study are financial feasibility analysis, land use optimization analysis, and multi-criteria analysis. The first analysis is financial feasibility analysis. It is applied to the asset management unit of financial condition for maximizing the income. The feasibility assessment parameter used is the net present value (NPV), a benefit-cost ratio (BCR) and internal rate of return (IRR) (Gittinger 1972). The analysis of land use optimization is done by using linear programming (LP). It illustrates that the main component of model based on the general structure of optimization model (mathematical programming) consisted of decision variables which are formulated by some variables value boundary function called constraint functions and objective functions (Intrilligator 1978). The multi-criteria analysis of geographic information system software (GIS) is used to decide the spatial distribution of land use (Kangas 2005; Purwanto et al. 2015). This is a main component of the supporting system in considering and accommodating all aspects by spatial perspective (Malczewski 2006, Arciniegas 2011).

According to the background above, it can be formulated some problems research, as follows:

1 How is financial feasibility to all collaborative management schemes into each management option?

2 Is the management option for each already optimized based on Lestari forest management criteria?

3 How is the spatial distribution of land use for each management option?

This study aims to analyze the optimization of the forest land use that provides the maximum income for $\mathrm{KPH}$ Pekalongan Barat.

The certain objectives of the study are:

1 To get the financial feasibility level of any kinds of land use in multiple-use management scheme.

2 To gain optimum vast for each of the land use.

3 To manage the land use allocation in multiple-use management by multi-criteria spatial analyzing.

This study is expected to provide some considerations in producing collaborative forest management scheme in Perum Perhutani especially for KPH Pekalongan Barat.

\section{Methods}

Location and research time This research is going to be done at forest management unit (KPH) of center Java regional (Figure 1). Administratively, KPH Pekalongan consists of five forest management units, namely: Bumijawa, Moga, Paguyangan, Bantarkawung, and Salem. This research merely focuses on the two forest management units those are Bumijawa and Salem. The collecting was done in

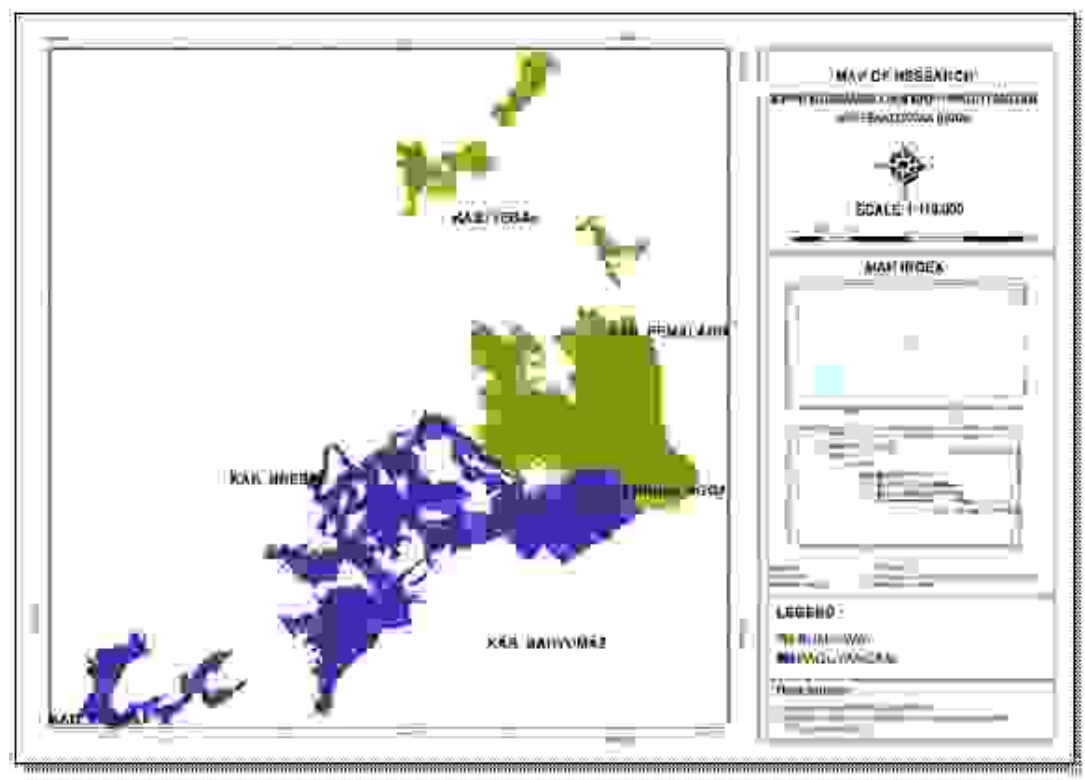

Figure 1 Research map. 
Table 1 Constraints function

\begin{tabular}{ll}
\hline Function & \multicolumn{1}{c}{ Information } \\
\hline $\mathrm{E}_{\mathrm{n}} \leq \mathrm{TE}$ & Existing erosion is not greater than the permissible erosion. \\
$\mathrm{L}_{\mathrm{Xn}}=13861$ & The total for all options is equal to the total area of existing BKPH of Paguyangan and Bumijawa. \\
$\mathrm{L}_{\mathrm{X} 1} \geq 9713$ & The size of pine can be wider than the existing condition. \\
$\mathrm{L}_{\mathrm{X} 2} \leq 2814$ & The size of coffee is not larger than the corresponding. \\
$\mathrm{L}_{\mathrm{X} 3} \leq 2312$ & The size of vegetable is not larger than existing size. \\
$\mathrm{L}_{\mathrm{X} 3} \leq 1032$ & The size of vegetable is not larger than corresponding. \\
\hline
\end{tabular}

Table 2 The use of actual land

\begin{tabular}{|c|c|c|c|c|}
\hline Landuse & Paguyangan & Bumijaya & Area $\left(\right.$ ha $\left.^{-1}\right)$ & Percentage (\%) \\
\hline Vegetable cultivation area & 1,947 & 353 & 2,300 & 16.6 \\
\hline Month Slamet & & 115 & 115 & 0.8 \\
\hline Pine Forest & 4,587 & 5,126 & 9,713 & 70.1 \\
\hline Vacant land & 965 & 770 & 1,732 & 12.5 \\
\hline Water & 1 & & 1 & 0.0 \\
\hline & Total & & 13,861 & 100.0 \\
\hline
\end{tabular}

Tabel 3 Erosion prediction based on land use

\begin{tabular}{lc}
\hline Land use & Average erosion $\left(\right.$ tons ha $\left.{ }^{-1}\right)$ \\
\hline Pine Forest & 2.08 \\
Coffee & 62 \\
Vegetable & 104 \\
\hline
\end{tabular}

Table 4 Area of land appropriate and not appropriate any commodity based on criteria

\begin{tabular}{|c|c|c|}
\hline Land suitability coffee & Area $\left(\mathrm{ha}^{-1}\right)$ & Percentage \% \\
\hline Corresponding & 2,814 & 20.30 \\
\hline Not Corresponding & 11,047 & 79.70 \\
\hline Total & 13,861 & 100 \\
\hline Land suitability vegetable & Area $\left(\right.$ ha $\left.^{-1}\right)$ & Percentage \% \\
\hline Corresponding & 1,032 & 20.30 \\
\hline Not corresponding & 12,829 & 79.70 \\
\hline Total & 13,861 & 100 \\
\hline
\end{tabular}

$\mathrm{KPH}$ Pekalongan Barat and the analyzing was done in Remote Sensing Laboratory, Forestry Faculty of IPB, Dramaga, Bogor. The research time started in November till December of 2015 and data analyzed in April-October 2016. Data Collecting

1 Primary data

The primary data in this research is a participative observation and in-depth interview to all informants that have related competencies with the study. Those informants are interviewed by the head of the forest management unit which is part of Bumijawa and Paguyangan, nine (9) of the heads of forest management resort, local government, and citizens.

2 Secondary data

Secondary data was collected by literature study of Perhutani and other organizations. Those data that 


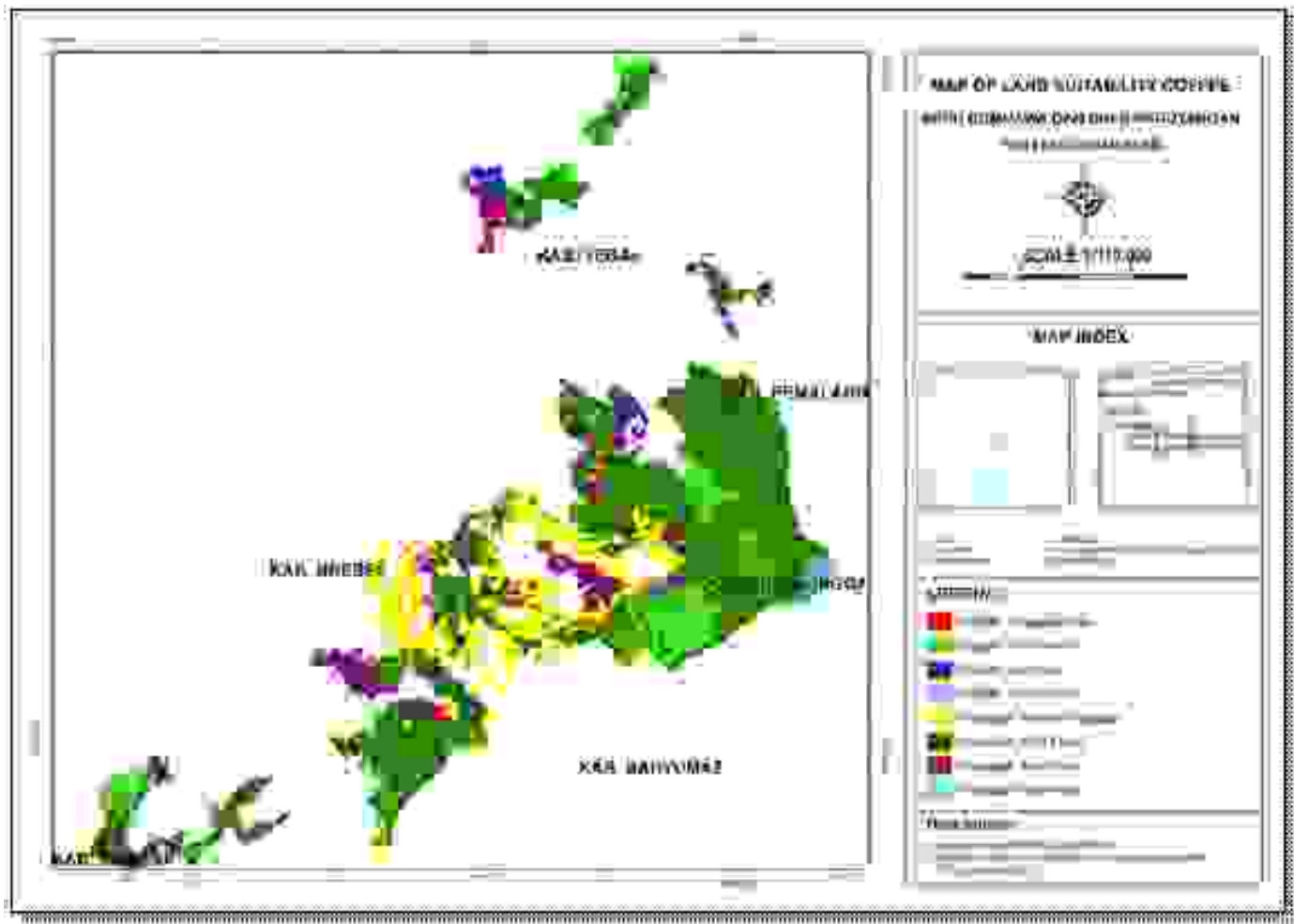

Figure 2 Map of land suitability coffee.

already been collected were a map (spatial) such as data of Perhutani site typology, data which influences the level of erosion like slope factor (LS), land use factor (C), and conservation effort factor (P). The financial data such as the start of each commodity investment data, operational data, and the price of each commodity.

Data analysis

1 Financial feasibility analysis

Analysis of Cost: To identify the various costs and the usual great unit for any land use activity. To rule of the cost incurred to time in accordance with the needs of the activity. To group the costs into two, namely: the investment cost and operating cost. The cost component will be inputted into preparing cash flow in order to analyze the financial feasibility.

Analysis of revenues: To identify any income on any existing commodity land use. To produce revenue of time according to the characteristics of each commodity. To group costs into two, namely: the investment cost and operating cost. To identify the level of income based on productivity and price of each commodity.

The financial viability of the forest management can be known by three eligibility types (Gittinger 1972): net present value (NPV) is the current value that reflects the value of profits earned by during a time period of management.

$$
\mathrm{NPV}=\uparrow_{\mathrm{t}=0}^{\mathrm{n}} \frac{(B t-C t)}{(1+i)^{n}}
$$

Note: $\mathrm{Bt}=$ benefits in year $\mathrm{t}, \mathrm{t}=$ Cost in year $\mathrm{t}, \mathrm{t}=$ year of business activity, $\mathrm{i}=$ interest rate used, $\mathrm{n}=$ Year- $\mathrm{t}$,

Benefit cost ratio (BCR) is the ratio between income and expenditure during the period of exploitation.

$$
B C R=\uparrow_{\mathrm{t}=0}^{\mathrm{n}} \frac{B_{t}}{(1+i)^{n}}
$$

Note $: 1=$ discount rate that results in a positive NPV, $2=$ discount rate that results in a negative NPV, $1=$ positive NPV, $2=\mathrm{NPV}$ is negative

Internal rate of return (IRR) is the maximum interest rate that can be paid by businesses or the ability to obtain income from money invested. IRR is a value discount rate that results in NPV $=0$.

$\operatorname{IRR}=\sum_{\mathrm{t}=0}^{\mathrm{n}} \frac{\left(B_{t}-C_{t}\right)}{(1+i)^{n}}=0$

Note $: \mathrm{Bt}=$ benefits in year $\mathrm{t}, \mathrm{Ct}=$ Cost in year $\mathrm{t}, \mathrm{i}=$ Discount rate $(\%), t=$ Year, $n=$ Year

The eligibility criterion of the forest utilization in this study is deemed feasibility if; BCR $>1$, the NPV is positive $(>0)$ and the IRR is greater than the discount rate.

2 Optimization Analysis of Land Use

Objective function: Maximize the revenue (NVP) with the following formula:

$$
\operatorname{Max} \uparrow_{t=1}^{3} N P V
$$

The total of NPV obtained by the following equation: $\mathrm{NPV}_{\text {total }}=\mathrm{L} \cdot \mathrm{NPVX} 1+\mathrm{L} \cdot \mathrm{NPVX} 2+\mathrm{L} \cdot \mathrm{NPVX} 3$ 
Note: $\mathrm{L}=$ total area of commodities, $\mathrm{X} 1=$ Commodity pine, $\mathrm{X} 2=$ Commodity Coffee, $\mathrm{X} 3=$ Commodity Vegetables, NPV = benefits of each commodity, Constraints Function

1 Environmental aspects (erosion)

The equation is used in erosion prediction methods based on the Universal Soil Loss Equation (USLE) (Wischmeir \& Smith 1978) and Tolerable Soil Loss (TSL) (Hammer 1981). $\mathrm{A}=\mathrm{R} \times \mathrm{K} \times \mathrm{LS} \times \mathrm{C} \times \mathrm{P}$

Erosion Rain ${ }^{\circledR}$. R factor is a number that indicates the amount of power index rainfall can cause the erosion. According to the conditions in the study area of research at the local area is relatively wide, fairly calculated from the data of the single station, in determining the value of $\mathrm{R}$ is determined based on the formula Lenvain (1975), which is derived from the sum of RM during a single year, as following:

$\mathrm{RM}: 2,21$ (Rain) $\mathrm{m}^{1,36}$

Note: RM: Erosion monthly rainfall, (Rain) m: Monthly rainfall $(\mathrm{cm})$

Erodibility of soil (K) Soil erodibility is a number that indicates the ease of soil particles peeled off from the soil aggregates by the onslaught of rain. The value of soil erodibility $(\mathrm{K})$ obtained by a previous research of $\mathrm{K}$ for some types of land.

Long and Slopes (LS) Paningbatan (2001) suggested that factors LS can also be derived simultaneously from a map of the percentage of slope (S) generated by using digital elevation maps (Digital Elevation Map-DEM) based on the following equation i.e. $\mathrm{LS}=0.2 \mathrm{~S} 1: 33+0.1$ in which $\mathrm{S}$ is the slope length. The equation is based on the results obtained the calculation of the index value LS.

Plant factor (C) Vegetation is very effective to control soil erosion through the modification of the amount of the erosion causing factors (Chang 2007). The effectiveness of vegetation in controlling the erosion rate is determined by characteristics such as the type, density, low height canopy, and the content of the litter. Calculation USLE erosion prediction method, the vegetation is one of the factors that most influence on the amount of soil erosion. Plants with a particular management also affect the amount of erosion of soil. On the contrary, the $\mathrm{P}$ factor is soil conservation (Arsyad 2007).

Conservation Factor (P). ASSESSMENT land management factors

Note: $(\mathrm{P})$ is based $\mathrm{ON}$ findings Field observations and factor Pvalues ON some research Arsyad (2007)

Erosion allowed/Tolerable to the soil loss (TSL) Erosion allowed is a matter of losing ground allowable amount per year; thus, the land productivity is not reduced in order the soil remains productive is still in a sustainable manner. The maximum soil loss is still tolerated by consideration of the genesis of the soil using a technical approach by Hammer (1981). TSL calculation is only used for the estimation of erosion scenario when creating scenarios erosion prediction based on value ranges.

$T S L=\frac{K E \subset F K}{U G T}$

Tolerable soil loss (TSL) is the maximum tolerable soil loss $\left(\mathrm{mm}\right.$ year $\left.^{-1}\right)$. KE is an effective soil depth $(\mathrm{mm})$. UGT is aged tenure and FK is a factor of soil depth. Delimitation of erosion rate that may be left is to be aware of the magnitude of erosion rate that can still be tolerated in a land both agricultural and non-agricultural lands, especially on sloped the slopes. It can be said theoretically that the rate of erosion should be balanced by the rate of soil formation, but it is very difficult to achieve this state of balance in practice.

1 Production aspect (Land suitability)

Land suitability analysis is done by assessing each land use that is feasibility for the option to manage the research sites that refers to the land suitability criteria (Hardjowigeno \& Widiatmaka 2001). Biophysical criteria assessed are in the form of rainfall, soil texture, soil type, and slope.

2 Social Aspect(Preferences)

It is about the determination of community preference (farmers) to land accessibility (distance from the road and the distance from settlements). The approach is taken by the interview and GIS analysis approach with the creation of buffers of the road network and the settlement distribution.

Information:

$\mathrm{Xn}=$ Option $\left(\mathrm{X}_{1}=\right.$ Pine, $\mathrm{X}_{2}=$ Coffee, $\mathrm{X}_{3}=$ Vegetable $), \mathrm{E}_{\mathrm{n}}=$ Erosion of land use (ton $\left.h^{-1}\right), L_{X_{n}}=$ Total area of the existing, $\mathrm{TE}=$ Total actual erosion

Multi-criteria analysis Multi-criteria analysis applies software queries on geographic information system (GIS). Multi-criteria approach is conducted to establish the location of land use that has resulted from the optimization analysis. This method can be used as a supporting tool in developing the spatial model that enables locations or areas are most suitable for each land use options (Jaimes et al. 2012). The map of the multiple criteria of data obtained from the search result (query) of the overlap (overlay) map based on multiple criteria. Criteria used in the determination of the area is the existing land use, the coffee land suitability, vegetable land suitability, a distance from the road and a distance from the settlement.

\section{Result and Discussion}

Actual conditions of land use. The general condition of the areas of KPH Pekalongan Barat have a field configuration in the form of land, choppy, hills and slopes and ravines as well as at a height of 60-3,432 $\mathrm{m}$ above sea level. This condition causes KPH Pekalongan Barat is in the area of Mount Slamet. The results obtained from the analysis above, the actual land use in BKPH Bumijawa and Paguyangan are pine forest of $9,713 \mathrm{ha}^{-1}(70.1 \%)$, the area of cultivation of vegetables amounted to $2,300 \mathrm{ha}^{-1}(16.6 \%)$ and the area vacant land $1,732 \mathrm{ha}^{-1}(12.5 \%)$. BKPH Paguyangan results in Bumijawa and ground check that the pine forest has been turned into vegetable fields and vacant land. The area vacant land location status was due to plant maintenance activities that failed. In addition to the difficult access and remote (steep topography) therefore making the lazy bug and prefer a location nearby. The soil conditions were dry, cracked, so a 
lot of dead plants. Most trees are only $50 \%$ productive, that other plant's failure. As a result of crop failure was also due to the cultivation of plants was done by pesanggem on a Perhutani's area. The information obtained in the field based on interviews shows that the land managed by them is under Perhutani's permission.

Environmental aspects (level erosion prediction) Land use classification carried erosion prediction use USLE calculation method. The results obtained for the total erosion of 256,992 tons year ${ }^{-1}$ of actual land use in the study site and BKPH Paguyangan BKPH Bumijawa. The estimation of the potential erosion of the options in this study is more emphasis on a modification of crop management factor (factor $\mathrm{C}$ ) because this factor is a factor that can fully engineer by erosion barrier function.

The average erosion on land use pine at 2.08 tons $\mathrm{ha}^{-1}$, land use coffee 62 tons $\mathrm{ha}^{-1}$ and the use of vegetable land erosion rate of 104 tons $\mathrm{ha}^{-1}$. The determining factor and the erosion are very high caused by value erosion are high of rainfall and steep slope grade class. The actual situation observed in the field is mostly people who plant vegetables in the forest area of BKPH Paguyangan dan Bumijawa BKPH become a supporting factor to a large amount of erosion. Erosion average for overall land use is 18.5 tons ha ${ }^{-1}$ Arsyad (1989) suggested that the maximum limit allowed for the erosion of soils in Indonesia is about 25 tons ha ${ }^{-1}$ year $^{-1}$. The erosion increased more into the tree that is not accompanied by undergrowth and litter. The tree canopy cover can slow down the rate of rainwater thus the kinetic energy becomes smaller (Asdak 2007). Besides, another factor is the effectiveness of vegetation can reduce the amount of rainwater to the ground. This is determined by the stratification of the canopy, vegetation density, presence or absence of vegetation cover and soil organic matter of the vegetation. Therefore, the erosion enlarged more into the tree which is not accompanied undergrowth and litter (Chang 2006).
Aspect production (land suitability) The results of a land suitability analysis are shown in Table 4 and suitability maps are shown in Figure 3 and Figure 4. The land suitability is done by determining a match between the quality and characteristic of the land in accordance with the growing requirements of the plants to be developed. The result obtained for the coffee option land use is 2,814 ha ${ }^{-1}$ and a vegetable option is around $1,032 \mathrm{ha}^{-1}$. All variable characteristics of the land assessed and compared with the criteria or requirements of coffee plants and vegetables which refer to the criteria (Hardjowigeno \& Widiatmaka 2001 ) in order to obtain a potential land suitability classes. An extent obtained by the land suitability analysis is used as a constraint (limiting factor) in the optimization model.

Social aspects (community preference) The optimum land use is also needed people's preferences in order to sustain a forest management. The result obtained from interviewing people's preferences related to the distance from any location options of using land that is a distance from the road and the distance from the settlement is $1-2 \mathrm{~km}$ from their home. The informants stated that the distance can be efficient in work. GIS analysis's result obtained vegetable location with the longest distance from the settlements is $6,000 \mathrm{~ms}$ and the shortest distance is around $2,000 \mathrm{~m}$. Other results for a distance from about $100 \mathrm{~m}$ settlements closest to farthest while is 5,600 m. Results of other GIS analyses indicate that there are multiple lanes to a footpath, another road and local road towards the forest area.

According to the distance preference for coffee and vegetable commodities to a large extent, the corresponding area is next to roads and settlements. Other results obtained, the distance from roads and settlements are not much different. Settlement point in around the area of research are numerous, and the road network is also found. Besides almost all areas close to the roads and settlements. Therefore, the social pressure is very high in a research area. Preferences distance is not inserted or not taken into

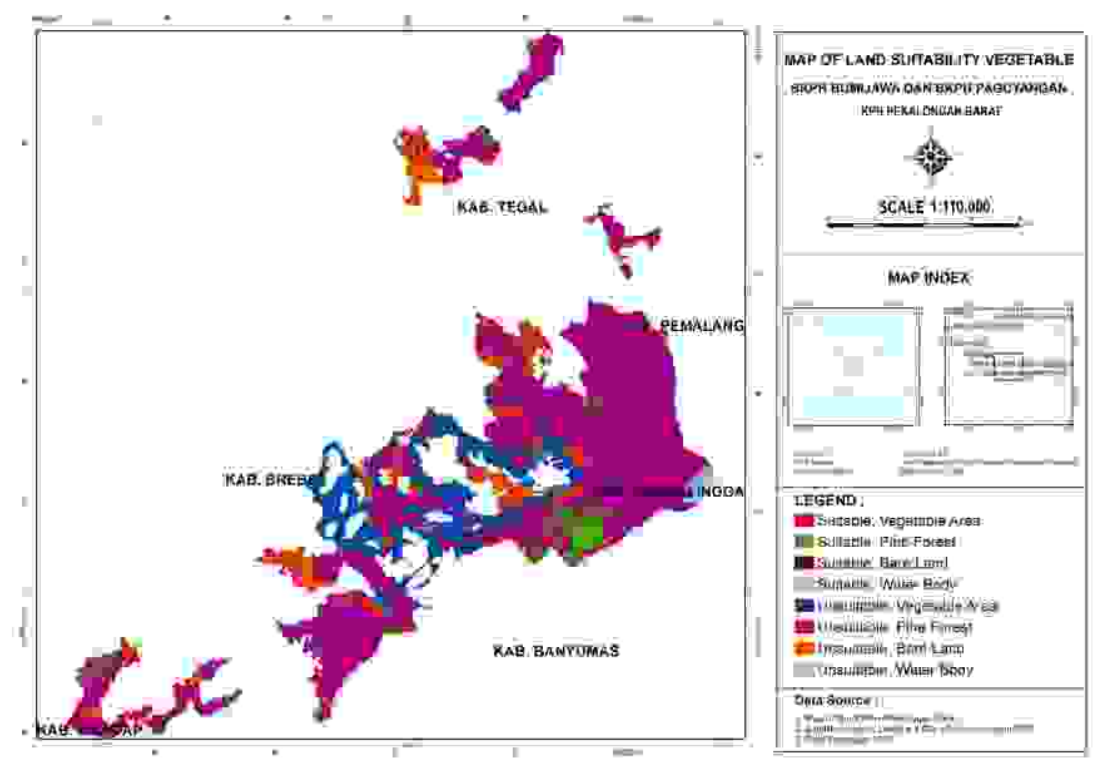

Figure 3 Map of land suitability vegetable. 


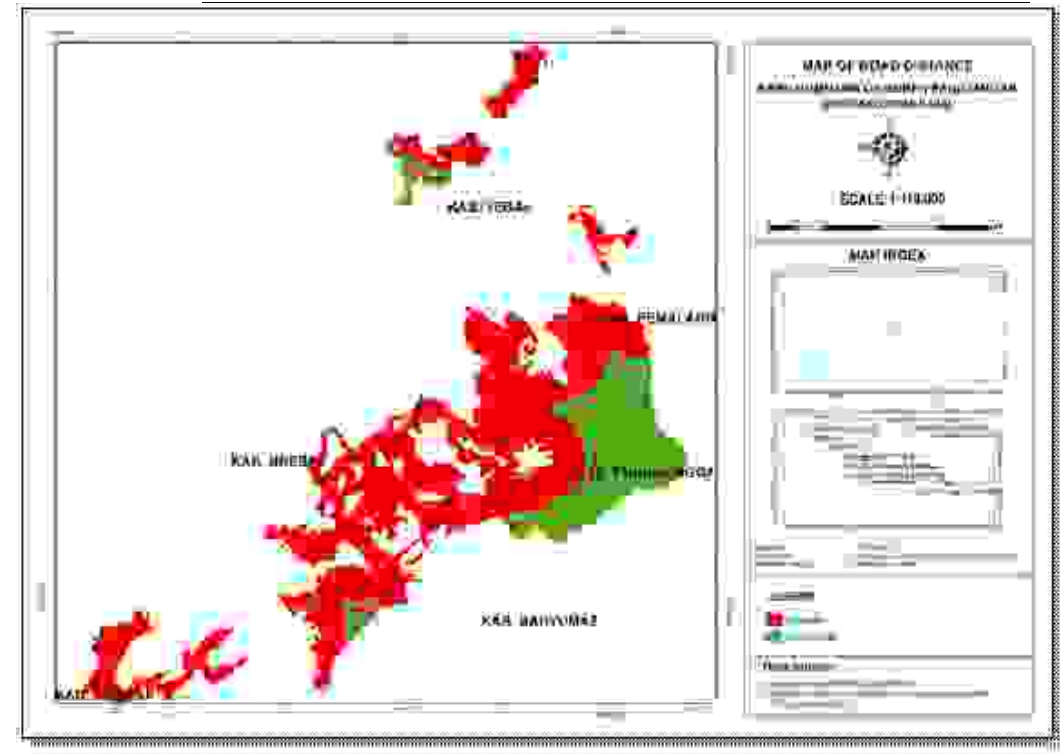

Figure 4 Map of road distance.

consideration of the optimization model. Bettinger (2009) explained that the forest sustainability depends on the maintenance of resources thus, there is no loss of quality in the future. It is not only ecological functions; the social criteria are also a very important thing in harmonizing various interests in forest management as well. Previous research conducted by Widodo (2007) indicated that the land closed to the road network has the potential and opportunity for the access to infrastructure and economic facilities. The closer to the road network, the potential of the land is much better. The closer to the resident areas with of plantation area enables the community to perform better in the land management process. Commodity vegetables and coffee, for example, needs an access to the road infrastructure to make it possible to be transported to the location of the factory on time (Obiechina 1986).

The feasibility analysis performed use discounted cash flow analysis (Gittinger 1986; Kadariah 1988). The third calculation investment eligibility criteria are based on a number of revenues and expenses during the operation of land-use options. Besides, the composition of production should also take into account the productivity of each commodity prices in the future due to the prices change have an important role in the calculation. The eligibility criteria, in this case, NPV is strongly influenced by economic parameters that will impact the composition of the optimal production (Wibowo et al. 2013). The feasibility of business can be judged by the criteria of investment.

Financial feasibility Net present value (NPV) is the net benefits value which is derived from the business during the period of governance options of pine, coffee, and vegetables. An attempt can be said to be feasible if the NPV is more than 0 and not feasible if it is less than 0 . On a scale of effort $<0.5$ $\mathrm{ha}^{-1}$, the results of the analysis show a positive NPV of IDR $26,357,247 \mathrm{ha}^{-1}$, in a business management option pine, the option of coffee governance also obtained NPV positive
IDR109,105,373 ha- ${ }^{-1}$. Conversely, the vegetable governance option $1 \mathrm{ha}^{-1}$ shows a positive NPV of IDR507,928,172 $\mathrm{ha}^{-1}$. NPV value generated on every scale enterprises surveyed explains that farming activity is feasible for NPV because NPV value is more than zero. The management of Arabica coffee, farmer cooperative members will result in the additional net benefit of NPV obtained from each business management option. Thus, it can be seen that an effort management options pine, coffee, and vegetables are feasible.

Net $\mathrm{B} / \mathrm{C}$ is the ratio between the net benefits which is positive $(\mathrm{PV}+)$ with the net benefit is negative (PV-) or net benefits that is lucrative business generated against the loss of the business unit. $\mathrm{B} / \mathrm{C}$ value acquired in business management option pine is $1: 51$, which means any additional cost incurred by one unit will produce additional net benefits to the farmers. In the coffee business management option acquire Net $\mathrm{B} / \mathrm{C} 1: 39$, while net $\mathrm{B} / \mathrm{C}$ obtained in the vegetable business management option is $1: 37$. The analysis shows that the $\mathrm{Net} \mathrm{B} / \mathrm{C}$ obtained from any attempt to manage the option value are more than 1 . This value indicates that the business of governance options has a favorable net benefit to the losses of the business unit that is feasible.

Internal Rate of Return analysis aims to determine how big the business returns on investment. IRR reflects the discount rate when it is used to discount the entire incoming cash which will generate cash amount equally to the amount of cash out. Discount Rate used in the analysis of management options is $6.5 \%$. The results of the analysis indicate that the IRR on the business management options pine is 1:37. On the coffee business management option shows a value of $26 \%$, while the business management option of vegetables is by $87 \%$. The effort of management option for each is executed because the IRR is more than the discount rate used.

The land use optimization The optimization results is 


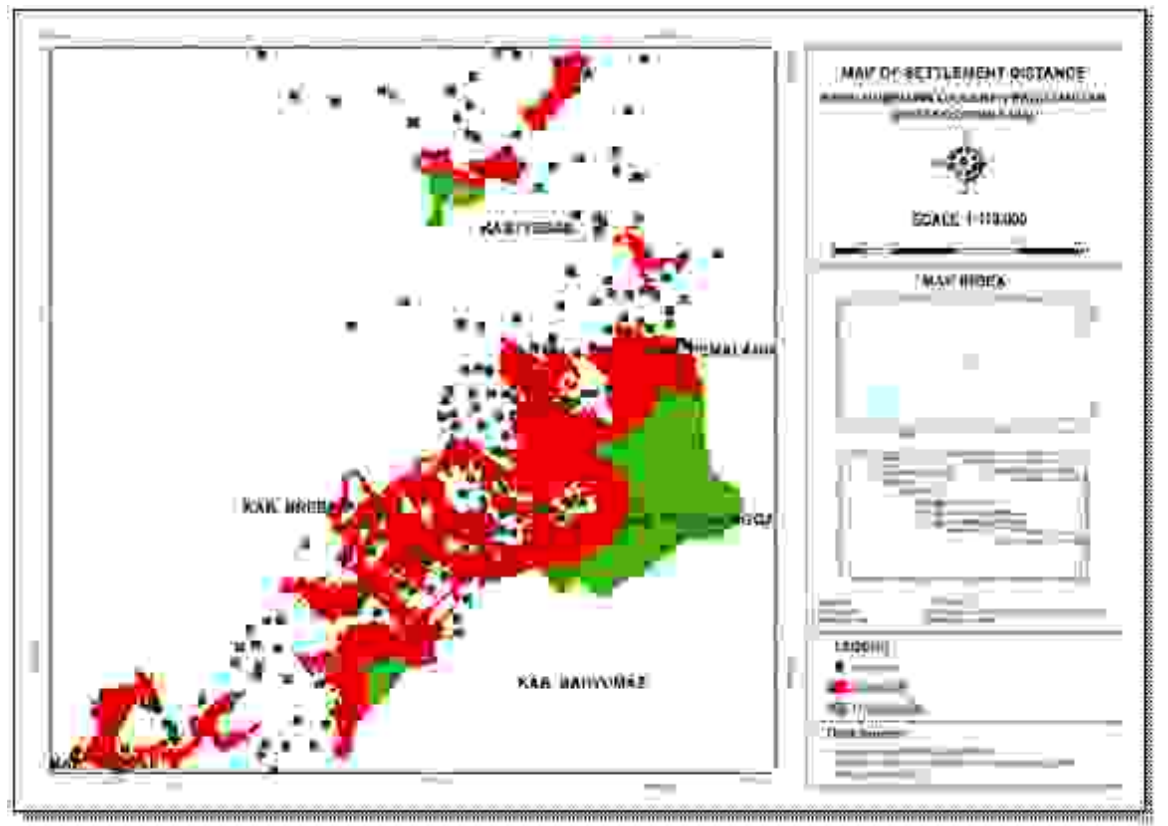

Figure 5 Map of settlement distance.

Table 5 Optimation model

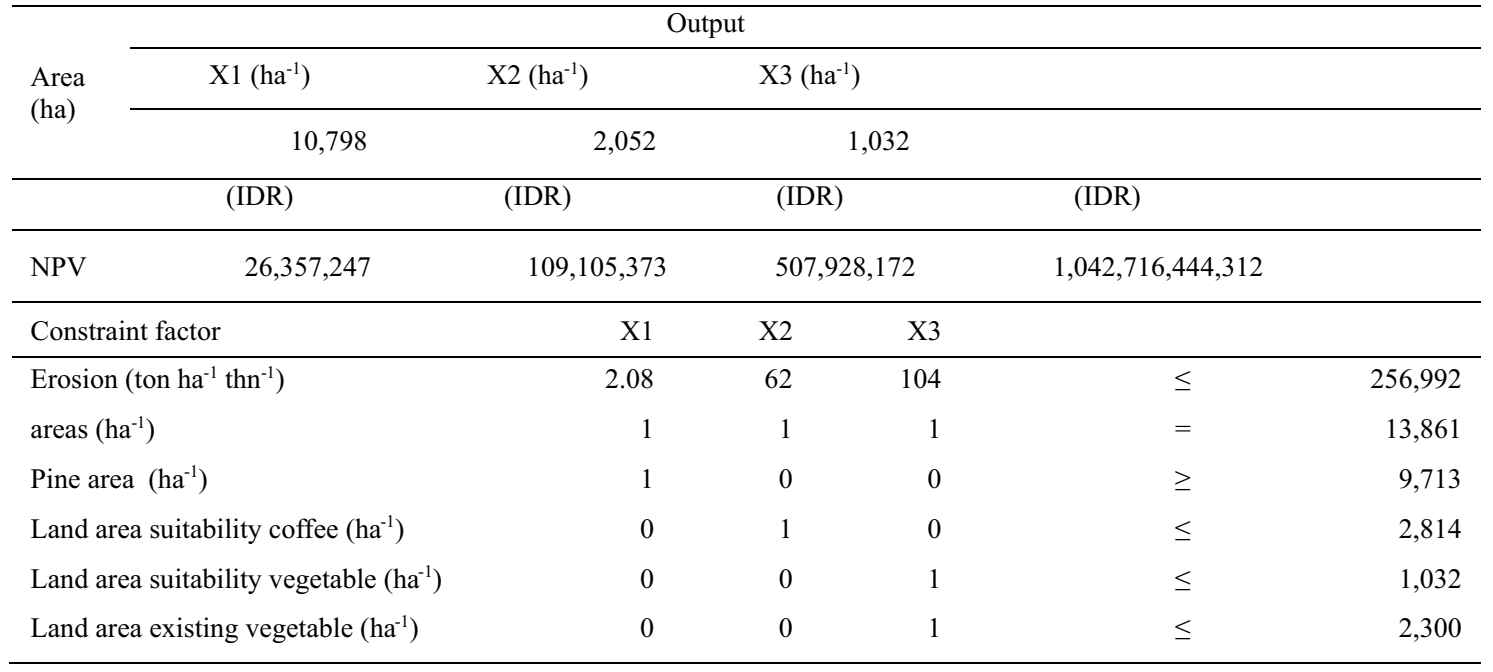

obtained with the maximum total revenue of IDR1,042,716,444.31. Each area (variable) is obtained for pine land (X1) covering an area of $10,798 \mathrm{ha}^{-1}$ and land area coffee (X2) is 2,052 ha $\mathrm{ha}^{-1}$, the details are shown in Table 5. Based on the results of the optimization, the area of $1,032 \mathrm{ha}^{-1}$ of a vegetable maximum extent and provide income is in under the existing extensive 2,312 ha $\mathrm{h}^{-1}$. The most influential factor constraints in the optimization models are the erosion factor. The determination of the erosion used in this model is the total erosion of existing land use at this time. Therefore, the determination of the value erosion that allowed the preparation is necessary to estimate erosion scenarios for optimization. This approach is based on the calculation of the value ranging from tolerable soil erosion (TSL) to actual erosion (USLE) as follows; The results obtained by calculating the erosion scenario in Table 6, TSL amounted to 84,943 tons year ${ }^{-1}$, then its range to $551 \mathrm{ha}^{-1}$ (minimum area). If the total erosion increasingly enlarged, the area of vegetable cultivation area is 1,032 ha (maximum size). Spacious obtained for commodity coffee is (zero) and by wide pine area $13,310 \mathrm{ha}^{-1}$ if the scenario is done by erosion allowed (TSL). If seen from the erosion of existing research, it is still a possible location for growing vegetables and coffee commodity. Table 6 above also indicates that if the amount of erosion resulting from growing the cotton area of vegetable commodities remain $1,032 \mathrm{ha}^{-1}$. Therefore, if it wants to minimize the extent of vegetable land, then both BKPH should implement soil conservation measures (KTA) and will pay the high costs. However, Katharina's research (2006) stated that farming potatoes in the long term 
Table 6 Multi-criteria model

\begin{tabular}{|c|c|}
\hline Coffee commodity area & Area \\
\hline $\begin{array}{l}\text { ("Coffee Land suitability", AND "Road distance, AND "Settlement distance" AND "Not a coffee } \\
\text { area") }\end{array}$ & $2,126 \mathrm{ha}$ \\
\hline Vegetable commodity area & \\
\hline $\begin{array}{l}\text { ("Vegetable land suitability", AND "Vegetable existing area" AND "Road distan ce } \\
\text { AND"Settlement distance") }\end{array}$ & 688 ha \\
\hline
\end{tabular}

by implementing soil conservation measures will provide higher returns.

The changes in land use will not bring a serious problem as long as it still follows the rules of soil and water conservation. The land use change will directly influence on the land cover characteristics that will affect the water system indicated by the response of the hydrological known through the production of water, erosion, and sedimentation (Seyhan 1990). Hardjowigeno \& Widiatmaka (2007) stated that the obstacle of water can be overcome by the irrigation water or irrigation system. Previous research pointed out that the conventional agriculture activity on the slopes will cause soil erosion and declining soil quality. Then, People earn relatively high cost for an unlimited time period (sustainable) and accompanied by soil and plants management techniques that produce smaller erosion of the erosion allowed (Hardjowigeno \& Widiatmaka 2007). The increasing rate of erosion at the study site also results in the decrease in crop production productivity which will bring about the lower income of farmer/community. Forest management model in obtaining the optimal land use is the management that supports the social and economic life of society and also is able to control erosion (Novierta et al. 2012). Other efforts in addressing the temporal pattern of erosion are to set the rotation of plants patterns which can restore soil conditions that have an impact on the spatial conditions (Huang et al. 2016).

Multi-criteria mapping Tutorial in determining the location (spatial) is presented in Table 6. Map of the area distribution which is obtained from the map data query of the overlay a few questions based on the criteria. Multi-Criteria is intended in this study to determine the location and extents according to the results of the optimization. Campbell et al. (1992) conducted a study to integrate the linear program with GIS by using land use planning allocation for the agricultural sector in Antiqua. The model of multiple criteria query is carried out, as follows:

\section{Pine forests}

Pine forest obtained from multiple criteria is 11,047 ha, while the condition of existing land use such as 7492 ha of pine forests followed by land covering an area of 1 401 ha, the area of vegetable cultivation is 2107 ha. Vacant land in this area is 1,402 ha, and the area of 2,108 ha of vegetable plots. Pine plantations are a class of KPH Pekalongan Barat company then retained and in case its suitability.

2 Coffee development area

Area of coffee develops into 2,126 ha-1, and the condition of existing land use shows a pine forest 1,700 ha-1, 233 ha-1 of vacant land, and the area 126 ha-1 cultivated vegetables. Wasteland and vegetables cultivated area can be used as a development area of the coffee that has been introduced by Perhutani. Previous coffee commodity development plans have been programmed by the administrator of KPH Pekalongan Barat. Coffee plant commodity will certainly remain planted under pine stands. The combination of these plants stands for controlling the intensity of the sun as needed, resulting in organic matter such as leaves to fertilize the soil, absorbing nutrients from the soil inside, resisting erosion, catching the wind, restraining the growth of some types of weeds, thereby reducing maintenance costs, reduce the occurrence of drought and as livestock feed.

Development of the coffee commodity itself also has an important role in minimizing erosion over the development of the coffee age (Pujianto et al. 2001). The amount of production of a commodity depends on soil quality, slope, rainfall, and altitude (Khan et al. 2014; Nzeimana et al. 2016). The corresponding area of the commodity which refers to the criteria Hardjowigeno and Widiatmaka (2001) is in the high-density forest. Decision-making model in a study with multiple criteria approach with GIS method has also been done before in Rwanda potential production area suitable for arabica coffee (Simunovic \& Nirupama 2005; Nzeyimana et al. 2016).

3 Vegetable development area

The area of commodity vegetable based on the result is $688 \mathrm{ha}$. The results of existing land use obtained the pine forests of 520 ha, 100 ha of vacant land, vegetable cultivation area is 66 ha and 1 ha of water. Constraints of the most dominant in the research area are the cultivation of vegetables on Perhutani forest area. Results of interviews with the people are done in order to improve the forest conditions. People will replace their crops with other crops. One of the planned management strategy management units in KPH Pekalongan Barat is replacing the vegetable cultivated area with coffee plants. KPH manages their business with KPH Pekalongan Barat coffee cultivation and it has been planned in advance. This will be conducted at locations that have become critical land and some of the locations filmed vegetables.

4 Vegetable cultivation area existing

The area existing vegetables only gets an area of $2,234 \mathrm{ha}^{-1}$ and it is not included in the criteria for based on the analysis of land suitability and vegetable cultivation area is 
now in the bad condition area. The vegetable cultivation area for the long term is not just reduced or removed but cannot be protected. Reduction of the existing area of vegetables is still possible to be changed gradually and then replaced with another commodity. People in the study site are not mostly using their own land, therefore they utilize Perhutani land. An increasing also saw in the growing population and needs of community life. Therefore, many forests works legally because it does not fully own by their owner. On the status of the function, the forest in two BKPH Protection Forest and Production and illegal logging activities. Then the vegetables cultivated area that has been there and then can also be replaced with other commodities to avoid the development of degraded areas. In addition to the coffee plants, an interview from the people shows that they want to plant cassava and grass for animal feed as well as take advantage of the tourism potential of the water. This can increase farmers' income thus it can adapt to the changing conditions of the market (economy), and reduce the pressure on forests. Their determination of the type/commodity is important because it relates to land suitability and desires of the community as well as the markets that had been built before. Selection of silver cultural techniques should also detail about the technique of determining the most optimum generateof revenue.

The allocation extents of some commodities such as pine forests, the area of the development of coffee and vegetable development in the area get the NPV of IDR872,581,112,943. The NPV results did not change much from the results of NPV optimization results, area map shown in Figure 6.

\section{Conclusion}

The growth (of height and diameter) at 18 months of sengon in progeny trials on two sites varies significantly across locations, between provenances, and between families within provenances. There was also significant family by site interaction for both traits. Estimations of individual heritability for both height and diameter were categorised as moderate with reasonable levels of additive genetic variation and there was a strong and positive genetic correlation between these two traits. Economic gains in growth traits can be expected from a recurrent selection and breeding program given the genetic parameters indicted in this study. The best option for future breeding strategy might be by separating the breeding population for each site and culling out highly susceptible individuals and retaining resistant individuals, for providing seed with good rust resistance.

\section{Acknowledgement}

The Analysis of land use optimization can be used as one of the instruments to formulate management options with collaborative management models in KPH Pekalongan Barat. The model of Collaborative forest management can be using agroforestry pattern to improve forest functions on vegetable planting area that has been built by the community in the purpose of sustainable forest management can be achieved.

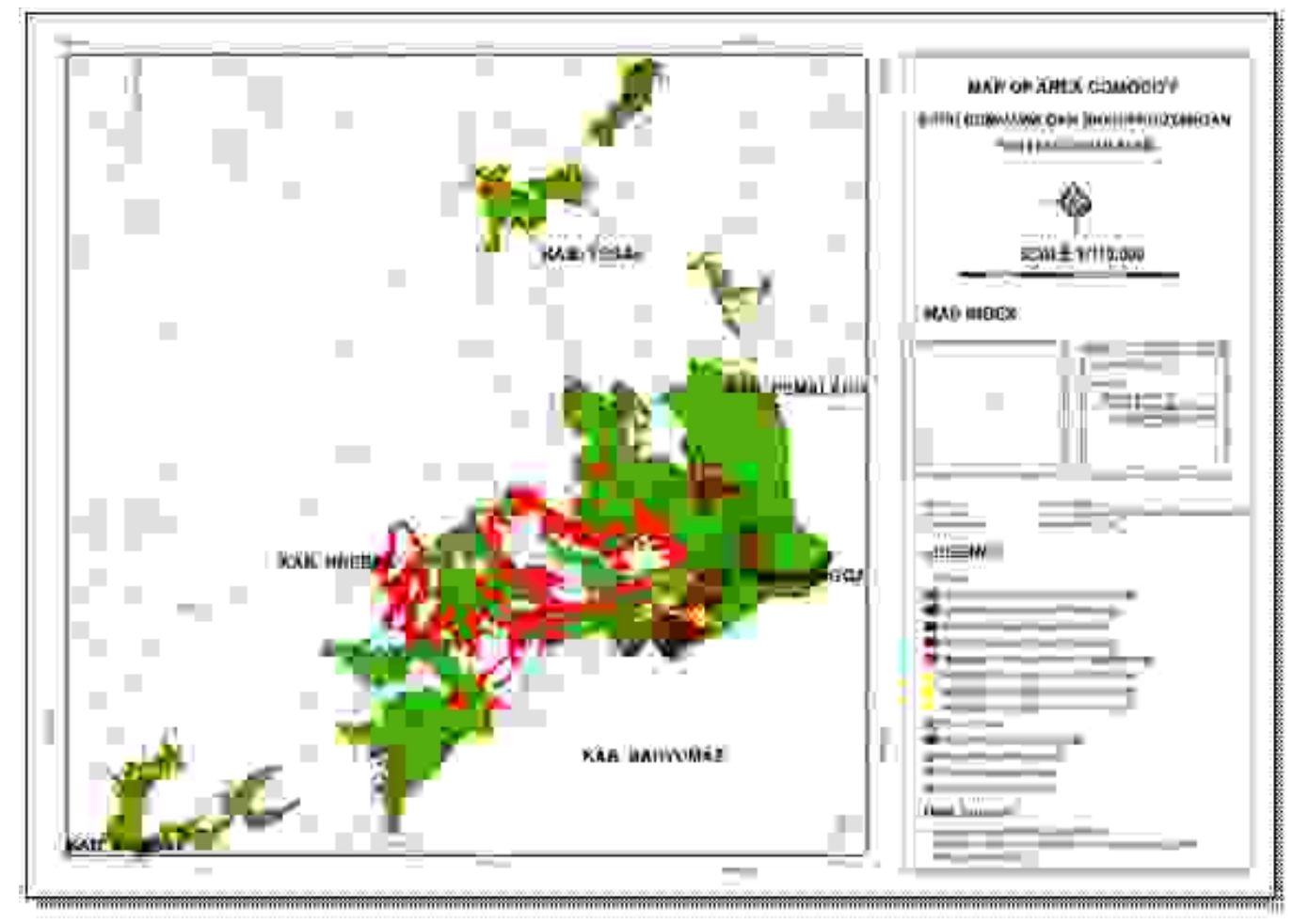

Figure 6 Map of area commodity. 


\section{References}

Asdak C. 2007. Hidrologi dan Pengelolaan Daerah Aliran Sungai. Yogyakarta: Gajah mada University Press.

Arciniegas G, Janssen G, Omtzigt N. 2011. Map-based multicriteria analysis to support interactive land use allocation. International Journal of Geographical Information Science 25:1931-194. https://doi.org/10. 1080/13658816.2011.556118

Bettinger P, Boston K, Surrey JP, Grebner D. 2009. Forest Management and Planning. Amsterdam: Academic Press.

Buongiorno J, Gilless JK. 2003. Decision Methods for Forest Resource Management. New York: Academic Press.

Bradshaw CJA, Sodhi NS, Peh KSH, Brook BW. 2007. Global evidence that deforestation amplifies flood risk and severity in the developing world. Global Change Biological 13:1-17. https://doi.org/10.1111/j.13652486.2007.01446.x.

Chang M. 2006. Forest Hydrology: An Introduction to Water and Forests 2nd ed. New York-USA: CRC Press Taylor and Francis Group.

Davis LS, Johnson KN, Bettinger PS, Howard TE. 2001. Forest management: to sustain ecological, economic, and Social Values. Fourth Edition. New York: McGrawHill.

Dewi S, Johana F, Ekadinata A, Agung P. 2014. Ferencanaan penggunaan lahan untuk strategi pembangunan rendah emisi (land-use planning for low-emission development strategies/luwes). Brief No. 38. Bogor, Indonesia. World Agroforestry Centre (ICRAF), Southeast Asia Regional Program.

Gittinger JP. 1972. Economic analysis of agricultural projects. paperback edition. the economic development institute of the world bank. Baltimore and London: The Johns Hopkins University Press.

Gittinger J. Price. 1986. Analisa ekonomi proyek-proyek pertanian. edisi kedua. Jakarta: UI-Press.

Hammer WI. 1981. Second Soil Conservation Consultant Report. Agof. Ins. 78:606(10).

Hardjowigeno S, Widiatmaka. 2001. Kesesuaian Lahan dan Perencanaan Tata Guna Lahan. Bogor: Jurusan Tanah Fakultas Pertanian IPB.

Hardjowigeno S, Widiatmaka. 2007. Kesesuaian lahan dan perencanaan tataguna tanah. Bogor: IPB

Hurkmans, RTWL, Terink W, Uijlenhoet R, Moors EJ, Troch PA, Verburg PH, 2009. Effects of land use changes on streamflow generation in the Rhine basin. Water Resources Research 45:1-15. https://doi.org/10. 1029/2008WR007574.
Huang W, Chak HP, Peng Y, Li L. 2016. Qualitative risk assessment of soil erosion for karst landforms in chahe town, southwest China: a hazard index approach. Catena144:184-193.

Intrilligator MD. 1971. Mathematical optimization and economic theory. Englewood Cliffs, New Jersey: Prentice-Hall Inc.

Jaimes NBP, Sendra JB, Delgado MG, Plata RF, Némiga XA, Solís LRM. 2012. Determination of optimal zones for forest plantations in the state of Mexico using multicriteria spatial analysis and GIS. Journal of Geographic Information System (4):204-218. https://doi.org/10.4236/jgis.2012.43025.

Kadariah. 1988. Evaluasi Proyek Analisis Ekonomi. Jakarta: Fakultas Ekonomi, Universitas Indonesia.

Kangas J, Store R, Kangas A. 2005 Socioecological landscape planning approach and multicriteria acceptability analysis in multiple-purpose forest management. Forest Policy and Economics 7:603-614. https://doi.org/10.1016/j.forpol.2003. 12.001 .

Katharina R. 2006. Faktor penyebab petani kentang lahan kering dataran tinggi kecamatan pangalengan, Bandung tidak mengadopsi konservasi tanah. Jurnal Ilmu Pertanian Indonesia 11(3):25-31.

Lin YP, Hong NM, Wu PJ, Lin CJ. 2007. Modeling and assessing land-use and hydrological processes to future land-use and climate change scenario in watershed land use planning. Environment Geology 53:623-634. https://doi.org/10.1007/s00254-007-0677-y.

Malczewski J. 2006. Integrating multicriteria analysis and geographic information systems: The ordered weighted averaging (OWA) approach. International Journal Environmental Technology and Management 6:7-19. https://doi.org/10.1504/ijetm.2006.008251.

Michon G, de Foresta H. 1999. Agro-forests: incorporating a forest vision in agroforestry. In: Buck LE, Lassoie JP, Fernandes ECM, Editors. Agroforestry in sustainable agricultural systems. Lewis Publishers.

Novierta, Jaya NS, Saleh MB. 2011. Optimasi penggunaan lahan dan penggunaan lahan menggunakan sistem informasi geografis di DAS Citamiang [thesis]. Bogor: Bogor Agricultural University.

Nzeyimana I, Hartemink AE, Geissen V. 2016. Gis-based multi-criteria analysis for arabica coffee expansion in Rwanda. PLoSONE 11(2).

Obiechina COB. 1986. An impact analysis of the development of the rural road system on the production of oil palm in imo state, Nigeria. Agricultural Systems 19:141-152. https://doi.org/10. 1016/0308-521X(86)9 0004-1. 
[Perhutani] Perusahaan Hutan Negara Indonesia. 2014. Rencana jangka panjang perum perhutani tahun 2015-2019. Jakarta: Perhutani.

Paningbatan E.P. 2001. Hydrology and soil erosion models for catchment research and management. in: Maglinao AR, Leslie RN, Editors. Soil Erosion Management Research in Asian.

Pujianto, Wibawa A, Winaryo. 2001. Pengaruh teras dan tanaman penguat teras terhadap erosi dan produktivitas kopi arabika. Pelita Perkebunan 17(1):18-29.

Purwanto J, Rusolono T, Prasetyo LB. 2015. Spatial model of deforestation in Kalimantan from 2000 to 2013. Jurnal Manajemen Hutan Tropika 21(3):110-118. https://doi.org/10.7226/jtfm.21.3.110.

[IPB] Fakultas Kehutanan Institut Pertanian Bogor. 2015. Penilaian Kinerja Perum Perhutani. Bogor: Faculty of Forestry Bogor agricultural University.

SeyhanE. 1990. Dasar-dasar Hidrologi. Yogyakarta: Gadjah Mada University Press.

Sinatala A. 2007. Konservasi Tanah dan Air. Bogor: IPB Press.

Simonovic SP, Nirupama A. 2005. A Spatial Multi-Objective Decision-Making Under Uncertainty for Water Resources Management. Journal of Hydroinformatics. 7: 117-133.
Suhendang E. 2005. Arah dan skenario pengembangan pemantapan kawasan hutan. kerjasama fakultas kehutanan ipb dengan departemen kehutanan. bogor: Fakultas Kehutanan Institut Pertanian Bogor.

Turner BL, Lambin EF, Reenberg A. 2007. The emergence of land change science for global environmental change and sustainability. Proceedings of the National Academy of Sciences 104(52):20666-20671. https://doi.org/10.1073/pnas.0704119104.

Wischmeier WH, Smith DD. 1978. Predicting rainfall erosion losses a guide to conservation planning. us. department of agriculture. Agriculture Hand Book. 537.

Wibowo AP, Rosyida FA, Firly RB. 2013. Application of linear programming in determining the composition of inland and offshore mining production of PT Timah (Persero), Tbk. Procedia Earth and Planetary Science 6:350-363. https://doi.org/10.1016/j.proeps.2013.01. 046.

Widodo E. 2007. Kajian pengaruh jalan terhadap kinerja perekonomian wilayah [thesis]. Bandung: Sekolah Pascasarjana, Institut Teknologi Bandung.

Xiao J, Shen Y, Ge J, Tateishi R, Tang C, Liang Y. 2006. Evaluating urban expansion and land use change in Shijiazhuang, China, by using GIS and remote sensing. Landscape and Urban Planning 75: 69-80. https://doi. org/10.1016/j.landurbplan.2004.12.005. 